\title{
Production of Wall Tiles Containing Ulexite Waste at Different Sintering Temperatures
}

\author{
Üleksit Atı̆̆ İçeren Duvar Karolarının Farklı Sinterleşme Sicaklıklarında Üretimi
}

\author{
Kemal KÖSEOĞLU ${ }^{1, a}$, Hakan CENGIZLER ${ }^{2, b}$, Lina İSRAEL İSRAİL*1,c \\ ${ }^{I}$ Ege Üniversitesi, Ege Meslek Yüksekokulu, Seramik Cam Çinicilik Programı, 35100, İzmir \\ ${ }^{2}$ Celal Bayar Üniversitesi, Turgutlu Meslek Yüksekokulu, Endüstriyel Seramik Programı,45410, Manisa
}

• Geliș tarihi / Received: 04.12.2019 • Düzeltilerek geliș tarihi / Received in revised form: 11.02.2020 • Kabul tarihi / Accepted: 04.03.2020

\begin{abstract}
Experimental compositions were prepared by the additions of ulexite concentrator waste to a standard wall tile body sintered at different temperatures. Tests of linear firing shrinkage, water absorption, and fired bending strength (eğilme mukavemeti) were done. XRD analyses were conducted to determine major crystalline phases in wall tile bodies. SEMEDX analyses were performed to study the microstructural evolution of the standard and experimental wall tile bodies. Colorimetric analyses were also made. The wall tile body containing 5 weight percent ulexite concentrator waste fired at $925^{\circ} \mathrm{C}$ for 6 minutes was determined to be the optimal composition with $0.60 \%$ of linear firing shrinkage, $17.66 \%$ of water absorption, and $208.60 \mathrm{of} \mathrm{kg} / \mathrm{cm}^{2}$ fired bending strength (eğilme mukavemeti). Sintering temperature was reduced from $1182^{\circ} \mathrm{C}$ of industrial practice down to $925^{\circ} \mathrm{C}$. Utilization of ulexite concentrator waste in tile bodies will help reduce energy costs in favour of the environment and economy.
\end{abstract}

Keywords: Sintering, Ulexite Waste, Wall Tile

$\ddot{O} z$

Üleksit konsantratör atığının standard duvar karosu bünyesine katılması ve değişik sicaklıklarda sinterleşmesiyle deneysel numuneler hazırlanmıştır. Doğrusal pişme küçülmesi, su absorpsiyonu ve pişme bükülme testleri yapılmıştır. $X$-ışınları kırınım analizleri duvar karolarının kristal fazlarını tayin etmekte; SEM-EDX analizleri standard ve deneysel duvar karolarının mikro yapılarındaki değişimlerin anlaşılmasında kullanılmıştır. Renk analizleri de gerçekleştirilmiştir. $925^{\circ} \mathrm{C}$ de 6 dakika pişirilen \%5 üleksit konsantratör atı̆̆ \% $\% .6$ doğrusal pişme küçülmesi, \%17.66 su emme ve $208.6 \mathrm{~kg} / \mathrm{cm}^{2}$ pişme bükülmesi değerleriyle optimum konsantratör atık derişimi olarak belirlenmiştir. Endüstriyel üretimde $1182^{\circ} \mathrm{C}$ olan sinterleşme sicaklı̆̆ $925^{\circ} \mathrm{C}$ ye düşürülmüştür. Üleksit konsantratör atığının duvar karolarında kullanımı enerji maliyetlerini düşürmeye yardım ederek ekonomi ve çevreye yarar sağlayacaktır.

Anahtar Kelimeler: Sinterleşme, Üleksit Atı̆̆ı, Duvar Karosu

*c Lina İSRAEL İSRAİL, lina.israil.01@ @mail.ege.edu.tr, Tel: 0(232) 3112939, orcid.org/0000-0002-0560-1839

a orcid.org/0000-0003-11,16-9103, $\quad{ }^{\mathrm{b}}$ orcid.org/0000-0001-5982-7692 


\section{Introduction}

Turkey was the seventh largest tile producer in the world and third in Europe. Besides, it was the fifth largest exporter in the world and third in Europe (Sezzi, 2004; Alp, 2005).

Boron minerals are very strategic and valuable raw materials. Their products are widely used in more than 200 fields of application (Önal and Burat, 2008). Eti Mine Works, the national mining enterprise of Turkey, produces concentrates of tincal, colemanite and ulexite (URL-1; Kurama et al., 2007; Ediz and Yurdakul, 2009; Kavas et al., 2011). Boron occurs as minerals associated with clay and other impurities in nature (Ediz and Yurdakul, 2009). Therefore, mineral processing methods are employed to obtain boron concentrates for further use in industry (Önal and Burat, 2008). During the ore treatment and refining processes to respectively produce boron concentrates and refined boron products of chemical purity (Önal and Burat, 2008), a substantial amount of different types of solid boron-containing wastes around 400.000 tons/year are formed and rejected in tailing dams or discharged in land fillings (Karasu et al., 2004; Kurama et al., 2006; Kurama et al., 2007; Önal and Burat, 2008; Ediz ve Yurdakul, 2009; Kavas et al., 2011). Boron is a known micronutrient, but high concentrations are deleterious for plants and materials containing high amounts of boron should be considered as a pollutant (Levinkas, 1964). Continuous accumulation of this large amount of industrial waste raises environmental concern. Because most boron compounds are easily dissolved in water which may result in severe environmental pollution when rains dissolve and carry these wastes to underground or surface water reservoirs (Ediz and Yurdakul, 2009). In particular, the dissolved boron compounds form several complexes with the heavy metals $(\mathrm{Pb}, \mathrm{Cu}, \mathrm{Co}, \mathrm{Ni}, \mathrm{Cd}$, etc.), which are more toxic than their metals (Boncukoglu et al., 2003). Some environmental effects came about due to boron mining and processing practised on a large scale in Turkey for almost 50 years (Önal and Burat, 2008). The $\mathrm{B}_{2} \mathrm{O}_{3}$ content of these wastes usually varies between 11 and 20 weight $\%$ depending on the initial minerals and the processing conditions (Kavas et al., 2011).

Ceramic industry is the large energy consumer especially due to drying and firing processes (Alp, 2005). Boron oxide-bearing minerals have a glassforming character and have been used in the ceramic industry to assist the amount of molten phase to increase and the sintering temperature to decrease acting as a fluxing agent (Kurama et al., 2006). The best way to supply cheap boron oxidebearing raw materials to ceramic industry as a fluxing agent is to incorporate boron containing wastes. A number of studies were carried out to utilize boron concentrator wastes in wall tile/tiles (WT) production (Karasu et al., 2002a,b,c, 2004; Ediz et al., 2004; Kurama et al., 2007; Çelik, 2015). However, these studies were related to the utilization of tincal and colemanite concentrator wastes of different chemical compositions. There were two previous works using additions of ulexite containing material (38.01 wt. \% ulexite content) (Bayca, 2009) and ulexite concentrator waste (UCW) (17.23 wt. \% ulexite content) (Koseoglu, 2017) in floor tile bodies. However, floor tile body compositions and process conditions are different from those of WT. Nevertheless, they reported encouraging results such as accelerated vitrification and improved liquid phase development leading to better properties. However, to the best of our knowledge, there was no study on the effect of UCW on the physico-mechanical properties and sintering behaviour of WT bodies.

The present study was therefore carried out to investigate the effect of various UCW additions on the physico-mechanical properties and the sintering behaviour of a standard (reference) WT body/bodies (SWTB) prepared commercially in a ceramic factory at various lower experimental temperatures than that of industrial practice. Experimental WT body/bodies (EWTB) were tested for linear firing shrinkage (LFS), water absorption (WA) and fired bending strength (eğilme mukavemeti-FBS) which were compared with those of the standard floor tile body (SWTB). XRD analyses were conducted for qualitative determination of major crystalline phases in SWTB and EWTB. SEM-EDX analyses were conducted to observe the microstructural evolution of both SWTB and EWTB. Correlation between the physico-mechanical properties and the phase and microstructural evolution of the fired EWTB was taken into consideration. The colorimetric analyses were also carried out to observe the change in colour of EWTB.

Waste recycling is a crucial issue of today's mining industry. Therefore, utilization of these wastes would help to ease the strain on environmental issues related to boron mining and would help to cut down expensive energy costs. In addition, this attempt would also be a favourable alternative from economical viewpoint due to the 
valuable $\mathrm{B}_{2} \mathrm{O}_{3}$ content of these wastes. Finally, a new product with potentially better properties would be an additional benefit.

\section{Materials and Methods}

\subsection{Raw Materials}

The body and the chemical composition of the SWTB prepared at Ege Seramik Factory (Polat Holding A.Ş., İzmir, Turkey) are seen in Table 1. The chemical analysis of UCW sample collected from the inflow to the tailings dam at Bigadiç Boron Company (Etibor Companies, Bandırma, Turkey) is seen in Table 2.

\subsection{Preparation of EWTB}

Five different compositions of EWTB were prepared (Table 3) and were coded as EWTB1,
EWTB3, EWTB5, EWTB7, and EWTB10 containing 1, 3, 5, 7 and 10 wt. \% UCW, respectively. The sieve analysis of the SWTB indicated that $96.88 \%$ of the material was under $63 \mu \mathrm{m}$ which is similar to those used industrially (Table 4).

A polypropylene ball mill (Maccihine Macine Schmalta) with alumina milling media was used to dry ground the as-received UCW sample to -63 $\mu \mathrm{m}$ for 3 hours. Various amounts of UCW were added to the SWTB and mixed to prepare the EWTB compositions (Table 3). The same polypropylene ball mill was employed to simultaneously mix and ground the materials for 5 minutes. A Sartorius BP 41005 digital scale was employed to weigh SWTB and EWTB to be $70 \mathrm{~g}$ each.

Table 1. Batch formula and chemical composition of SWTB.

\begin{tabular}{|c|c|c|c|c|c|c|c|c|c|c|c|c|c|}
\hline & $\%$ & & LOI & $\mathrm{SiO}_{2}$ & $\mathrm{Al}_{2} \mathrm{O}_{3}$ & $\mathrm{Fe}_{2} \mathrm{O}_{3}$ & $\mathrm{TiO}_{2}$ & $\mathrm{CaO}$ & MgO & $\mathrm{SO}_{3}$ & $\mathrm{Na}_{2} \mathrm{O}$ & $\mathbf{K}_{2} \mathrm{O}$ & $\mathbf{P}_{2} \mathrm{O}_{5}$ \\
\hline Calcite & 6.5 & & 43.54 & 0.58 & 0.15 & 0.19 & & 55.00 & 0.47 & 0.08 & & & \\
\hline Kaolinite & 6 & & 7.01 & 68.96 & 20.47 & 1.54 & 0.26 & 0.26 & 0.15 & 0.84 & 0.26 & 0.26 & \\
\hline \multirow[t]{4}{*}{ Silica } & 5 & & 2.09 & 90.15 & 5.43 & 0.75 & 1.07 & 0.12 & 0.07 & & 0.14 & 0.15 & 0.03 \\
\hline & & A & 6.76 & 59.84 & 17.46 & 6.73 & 0.80 & 2.61 & 1.80 & & 0.67 & 3.12 & 0.11 \\
\hline & & B & 10.39 & 52.99 & 27.92 & 3.22 & 1.07 & 0.83 & 1.25 & 0.15 & 0.34 & 1.74 & 0.05 \\
\hline & 51 & $\mathrm{C}$ & 5.35 & 66.28 & 19.66 & 2.43 & 1.08 & 0.16 & 0.84 & & 0.54 & 3.66 & \\
\hline Clay & & D & 7.36 & 61.48 & 23.18 & 2.65 & 1.23 & 0.15 & 0.67 & & 0.34 & 2.95 & \\
\hline Pumice & 9.5 & & 4.28 & 72.40 & 12.54 & 1.6 & & 0.54 & 0.11 & & 2.59 & 6.4 & \\
\hline Sand & 22 & & 2.87 & 76.02 & 13.70 & 1.02 & 0.47 & 0.36 & 0.52 & & 1.48 & 3.56 & \\
\hline
\end{tabular}

Table 2. Chemical analysis of UCW (on dry basis, not including moisture and LOI).

\begin{tabular}{ccccccccccc}
\hline Oxide & $\mathrm{B}_{2} \mathrm{O}_{3}$ & $\mathrm{SiO}_{2}$ & $\mathrm{Al}_{2} \mathrm{O}_{3}$ & $\mathrm{Fe}_{2} \mathrm{O}_{3}$ & $\mathrm{SrO}$ & $\mathrm{MgO}$ & $\mathrm{CaO}$ & $\mathrm{Na}_{2} \mathrm{O}$ & $\mathrm{K}_{2} \mathrm{O}$ & $\mathrm{LOI}$ \\
$(\%)$ & 17.23 & 10.98 & 0.80 & 0.15 & 0.96 & 10.70 & 12.20 & 6.67 & 0.30 & 39.37 \\
\hline
\end{tabular}

Table 3. Batch formulas of SWTB and EWTB containing different UCW additions.

\begin{tabular}{ccccccc}
\hline WT formula & SWTB & EWTB1 & EWTB3 & EWTB5 & EWTB7 & EWTB10 \\
\hline Calcite (\%) & 6.5 & 6.5 & 6.5 & 6.5 & 6.5 & 6.5 \\
Kaolinite (\%) & 6 & 6 & 6 & 6 & 6 & 6 \\
Silica (\%) & 5 & 5 & 5 & 5 & 5 & 5 \\
Clay (\%) & 51 & 50 & 48 & 46 & 44 & 41 \\
Pumice (\%) & 9.5 & 9.5 & 9.5 & 9.5 & 9.5 & 9.5 \\
Sand (\%) & 22 & 22 & 22 & 22 & 22 & 22 \\
UCW (\%) & 0 & 1 & 3 & 5 & 7 & 10 \\
\hline
\end{tabular}


Table 4. Sieve analysis of SWTB.

\begin{tabular}{llll}
\hline Screen size $(\boldsymbol{\mu m})$ & Weight $(\boldsymbol{\%})$ & Cumulative under size $(\boldsymbol{\%})$ & Cumulative over size $(\boldsymbol{\%})$ \\
\hline+125 & 0.07 & 100.00 & 0.07 \\
$-125+100$ & 0.27 & 99.93 & 0.34 \\
$-100+63$ & 2.78 & 99.66 & 3.12 \\
$-63+45$ & 5.23 & 96.88 & 8.35 \\
$-45+32$ & 9.29 & 91.65 & 17.64 \\
-32 & 82.36 & 82.36 & 100.00 \\
Total & 100 & & \\
\hline
\end{tabular}

\subsection{Processing and Characterization of EWTB}

The mixtures were dried in a laboratory drying oven (NÜVE KD 400) at $110{ }^{\circ} \mathrm{C}$ for 1 hour and were moisturized with 6 wt. \% water for shaping. They were then placed in a $5 \mathrm{~cm} \times 10 \mathrm{~cm} \times 0.5 \mathrm{~cm}$ steel die and uniaxially pressed with a hydraulic press (SACMI 470, PIL type) under $27 \mathrm{MPa}$ pressure. The pressed green tiles were firstly dried at $110{ }^{\circ} \mathrm{C}$ for 1 hour and were fired in a laboratory electrical muffle furnace (Nabertherm G100/9) at 925,975 , and $1025^{\circ} \mathrm{C}$ for dwelling times of 6 and $30 \mathrm{~min}$ under conditions simulating industrial practice. It must be noted that the industrial firing temperature and dwelling time at Ege Seramik Factory was $1182{ }^{\circ} \mathrm{C}$ and 6 minutes, respectively. The EWTB were then allowed to cool down to the room temperature in the furnace.

\subsection{Characterization of $E W T B$}

LFS, WA and FBS values of sintered WT were determined through physical and mechanical tests carried out at the quality-control department of Ege Seramik Factory in accordance with TS EN ISO 10545-2, TS EN ISO 10545-3 and TS EN ISO 10545-4. The FBS tests were performed in a Gabrielli Crometro CR4-A4-B4 hydraulic press. Three EWTB were prepared and fired for each test condition (Table 4) and the average values of LFS, WA and FBS were calculated in order to provide better representation of the resuts. LFS, WA and FBS values obtained were compared with those of the SWTB.

Major crystalline phases present in the SWTB and the selected EWTB were qualitatively determined by X-Ray diffraction (XRD) on powder samples using a Rigaku Miniflex II X-Ray powder diffractometer with Ni-filtered $\mathrm{Cu} \mathrm{K} \alpha(\lambda=1.54 \AA)$ radiation in the $5-80^{\circ} 2 \theta$ range at $30 \mathrm{kV}$ and $15 \mathrm{~mA}$. A JEOL JSM 6060 scanning electron microscope
(SEM) attached with a JEOL Energy dispersive $\mathrm{X}$ - ray (EDX) spectrometer was used for microstructural observations. Polished crosssections were produced by mounting sample fragments in low viscosity epoxy resin and polishing to a $1 \mu \mathrm{m}$ finish. Samples were coated with a thin layer of Pt prior to SEM imaging. The colorimetric analyses of WT were carried out at Ege Seramik Inc. using an Erichsen Spectromaster 565-D according to EN ISO 10545-16.

\section{Results and Discussion}

\subsection{Physico-mechanical Properties}

The results of the experimental tests carried out to determine the physico-mechanical properties of WT, namely LFS, WA, FBS, and colouring parameters are presented in Table 5. As can be seen, the LFS values increased with an increase in the UCW content at all compositions, sintering temperatures, and dwelling times, which was in agreement with the previous studies using wastes of other boron bearing minerals (Karasu et al., 2002a,b,c, 2004; Ediz et al., 2004; Kurama et al., 2006; Kurama et al., 2007; Bayca, 2009). Increase in LFS values with increasing UCW ratio can be ascribed to enhancement in vitrification due to the generation of glassy phase, which filled the pores already present in the WT body structure. It was seen that UCW assisted glassy phase to form easier at all sintering temperatures because of its $\mathrm{B}_{2} \mathrm{O}_{3}, \mathrm{MgO}, \mathrm{Na}_{2} \mathrm{O}$ and $\mathrm{Fe}_{2} \mathrm{O}_{3}$ content (Table 2) which all built up a powerful fluxing action as a low temperature auxiliary flux (Kurama et al., 2006). Therefore, the LFS values increased while the porosity decreased. In most cases, the LFS values of EWTB with 30 minutes holding time were higher than those with 5 minutes holding time. Longer dwelling time promoted sintering and caused higher amount of glassy phase formation that filled the pores. The LFS values 
also increased with increasing sintering temperatures. Increased temperature led to higher levels of glassy phase formation again causing a decrease in the pore numbers.

As the degree of sintering progressed, the amount of molten phase increased and correspondingly some of the pores, already built up in interparticle voids during sintering, disappeared completely while the rest were surrounded by the molten glassy phase of lower viscosity forming closed pores in the structure. Thus, slowly collapsing open pores in initial structure led to partial shrinkage (Coble, 1961; Coble and Burke, 1963; Thümmler and Thomma, 1967; Carter and Norton, 2013). Therefore, increasing UCW content, longer dwelling time and higher sintering temperature enhanced the degree of sintering with an increase in the LFS values.

As expected, the WA values decreased with increasing UCW content and LFS values for all sintering temperatures, compositions, and dwelling times (Table 5). The fluxing effect of UCW promoted vitrification and thereby formation of glassy phase, which filled the initial pores in the body structure (Coble, 1961; Coble and Burke, 1963; Thümmler and Thomma, 1967; Carter and Norton, 2013). The decrease in WA values at higher sintering temperatures and longer soaking times was again due to higher levels of glassy phase formation causing a decrease in the pore numbers as explained above.

The FBS values, in most cases, also increased with increasing amount of UCW, longer dwelling time, and higher sintering temperature (Table 5).

One of the criteria in choosing the best WT recipe was to use as high ratio of UCW as much as possible for maximum waste recycling. The second criterion was to employ lowest sintering temperature possible with shortest dwelling time for energy conservation. When these criteria and the conformity of physico-mechanical properties to the required standards (TS EN ISO 10545-2 2000; TS EN ISO 10545-3 2000; TS EN ISO 10545-4 2000) were taken into account, the optimal EWTB composition was found to be EWTB5 fired at $925^{\circ} \mathrm{C}$ for 6 minutes. In this case, the LFS, WA, and FBS values were $0.60 \%, 16.15$ $\%$, and $208.60 \mathrm{~kg} / \mathrm{cm}^{2}$, respectively (Table 5). In the present study, when compared with the properties of SWTB, 5 wt. \% UCW addition decreased the LFS value by $41 \%$, and increased the WA and the FBS values by $2.4 \%$ and $2.7 \%$, respectively. This result translated itself as an improvement in the physical and mechanical properties of SWTB (Table 5). Besides, sintering temperature was significantly reduced from 1182 ${ }^{\circ} \mathrm{C}$ down to $925^{\circ} \mathrm{C}$, which will contribute to lower energy costs, considerably. 5 wt. \% UCW addition improved the physical and mechanical properties of SWTB (Table 5).

\subsection{Phase Analysis}

As seen from Table 2, the UCW contains a high ratio of fluxing oxides such as alkali $\mathrm{B}_{2} \mathrm{O}_{3}, \mathrm{Na}_{2} \mathrm{O}$, $\mathrm{K}_{2} \mathrm{O}$, earth alkali $\mathrm{CaO}, \mathrm{MgO}$, and $\mathrm{Fe}_{2} \mathrm{O}_{3}$ which play an important role in the vitrification behaviour of WT bodies and help liquid phase to form easily at lower temperatures during sintering (Coble, 1961; Coble and Burke, 1963; Thümmler and Thomma, 1967; Singer and Singer, 1984; Glendenning and Lee, 1996; Carter and Norton, 2013). According to the XRD analysis (Figure 1), UCW composed of ulexite, colemanite, quartz, and dolomite. Figures 2 and 3 show the XRD spectra of SWTB and EWTB5 (optimal composition), respectively. As seen from Figure 3 main crystalline phases in UCW, upon firing of EWTB5, disappeared and transformed into new phases of mullite $\left(3 \mathrm{Al}_{2} \mathrm{O}_{3} \cdot 2 \mathrm{SiO}_{2}\right)$, albite $\left(\mathrm{Na}_{2} \mathrm{O} \cdot \mathrm{Al}_{2} \mathrm{O}_{3} \cdot 6 \mathrm{SiO}_{2}\right)$ and hematite $\left(\mathrm{Fe}_{2} \mathrm{O}_{3}\right)$. It was also noticed that no new phase formation took place with UCW additions to the SWTB (Figure 2). However, the peak intensity of these phases in SWTB was reduced (Figures 2 and 3). It is known that borates decrease the melting temperature of the glass and act as an important glass builder. Alkali and alkaline earth oxides in borates break up the bonds between silicon and oxygen in the glass structure. This effect reflects itself as a lower glass phase viscosity with increasing temperature (Glendenning and Lee, 1996; Baele, 1998). In the present investigation, UCW assisted the glassy phase to form more easily during sintering due to its fluxing capacity. Therefore, the proportion of glassy phase was higher in EWTB5. The phases of albite, mullite and hematite in the fired SWTB were partly dissolved in the low viscosity glass phase formed by high alkali fluxing type of oxides (Karasu et al., 2004; Kurama et al., 2006; Kurama et al., 2007; Ediz and Yurdakul, 2009) of UCW (Table 5). Therefore, the peak intensities of those crystalline phases were reduced in the XRD patterns of EWTB5 (Figures 2 and 3). The raw material of WT and UCW originally comprised quartz as an unreacted residue in SWTB and EWTB5 to a large extent. Quartz, mullite, albite and hematite were the main crystalline phases in the structure of sintered EWTB and EWTB5 (Figures 2 and 3). 
Table 5. Physico-mechanical properties of SWTB and EWTB sintered at 925,975 , and $1025^{\circ} \mathrm{C}$.

\begin{tabular}{|c|c|c|c|c|c|c|c|}
\hline Sample & $\begin{array}{c}\text { Temperature and } \\
\text { time }\end{array}$ & LFS (\%) & FBS $\left(\mathrm{kg} / \mathrm{cm}^{2}\right)$ & WA (\%) & $\mathbf{L}$ & $\mathbf{a}$ & $\mathbf{b}$ \\
\hline SWTB & $1182^{\circ} \mathrm{C}(6$ min.* $)$ & 1.01 & 203.18 & 15.78 & 72.11 & 9.89 & 19.47 \\
\hline EWTB1 & $925^{\circ} \mathrm{C}(6 \mathrm{~min})$. & -0.20 & 88.66 & 17.51 & 72.08 & 13.93 & 26.78 \\
\hline EWTB3 & $925^{\circ} \mathrm{C}$ (6 min.) & -0.02 & 134.70 & 17.02 & 67.84 & 15.75 & 28.45 \\
\hline EWTB5 & $925^{\circ} \mathrm{C}$ (6 min.) & 0.60 & 208.60 & 16.15 & 62.15 & 17.91 & 27.89 \\
\hline EWTB7 & $925^{\circ} \mathrm{C}$ (6 min.) & 1.48 & 221.20 & 14.88 & 54.98 & 19.72 & 26.68 \\
\hline EWTB10 & $925^{\circ} \mathrm{C}(6 \mathrm{~min})$. & 3.18 & 254.00 & 48.34 & 48.34 & 18.12 & 22.22 \\
\hline SWTB & $1182^{\circ} \mathrm{C}$ (6 min.) & 1.01 & 203.18 & 15.78 & 72.11 & 9.89 & 19.47 \\
\hline EWTB1 & $925^{\circ} \mathrm{C}$ (30 min.) & -0.10 & 98.28 & 18.14 & 69.86 & 14.94 & 27.34 \\
\hline EWTB3 & $925^{\circ} \mathrm{C}$ (30 min.) & 0.28 & 144.04 & 16.53 & 64.35 & 17.55 & 28.61 \\
\hline EWTB5 & $925^{\circ} \mathrm{C}$ (30 min.) & 1.10 & 181.06 & 14.52 & 57.57 & 19.63 & 27.77 \\
\hline EWTB7 & $925^{\circ} \mathrm{C}$ (30 min.) & 2.64 & 268.70 & 29526 & 50.80 & 19.68 & 24.62 \\
\hline EWTB10 & $925^{\circ} \mathrm{C}$ (30 min. $)$ & 6.26 & 368.00 & 4.77 & 44.38 & 15.91 & 18.88 \\
\hline SWTB & $1182^{\circ} \mathrm{C}$ (6 min.) & 1.01 & 203.18 & 15.78 & 72.11 & 9.89 & 19.47 \\
\hline EWTB1 & $975{ }^{\circ} \mathrm{C}$ (6 min.) & 0.04 & 97.89 & 17.87 & 70.81 & 13.62 & 26.22 \\
\hline EWTB3 & $975^{\circ} \mathrm{C}$ (6 min.) & 0.86 & 200.40 & 15.14 & 60.81 & 17.50 & 26.65 \\
\hline EWTB5 & $975^{\circ} \mathrm{C}$ (6 min. $)$ & 2.10 & 236.20 & 12.46 & 53.21 & 18.22 & 24.10 \\
\hline EWTB7 & $975^{\circ} \mathrm{C}$ (6 min.) & 3.32 & 243.20 & 10.27 & 48.70 & 17.64 & 22.02 \\
\hline EWTB10 & $975^{\circ} \mathrm{C}$ (6 min.) & 3.78 & 258.10 & 7.72 & 46.77 & 17.06 & 20.63 \\
\hline SWTB & $1182^{\circ} \mathrm{C}$ (6 min.) & 1.01 & 203.18 & 15.78 & 72.11 & 9.89 & 19.47 \\
\hline EWTB 1 & $975^{\circ} \mathrm{C}$ (30 min.) & 0.16 & 158.70 & 17.52 & 67.59 & 15.45 & 26.96 \\
\hline EWTB3 & $975^{\circ} \mathrm{C}$ (30 min.) & 1.04 & 225.70 & 13.81 & 58.78 & 18.95 & 26.97 \\
\hline EWTB5 & $975^{\circ} \mathrm{C}$ (30 min. $)$ & 3.52 & 318.70 & 9.49 & 48.97 & 17.69 & 21.91 \\
\hline EWTB7 & $975^{\circ} \mathrm{C}$ (30 min.) & 6.72 & 388.50 & 3.94 & 42.43 & 14.88 & 17.43 \\
\hline EWTB10 & $975^{\circ} \mathrm{C}$ (30 min.) & 8.60 & 392.50 & 0.07 & 41.25 & 10.88 & 13.59 \\
\hline SWTB & $1182^{\circ} \mathrm{C}$ (6 min.) & 1.01 & 203.18 & 15.78 & 72.11 & 9.89 & 19.47 \\
\hline EWTB 1 & $1025^{\circ} \mathrm{C}$ (6 min.) & 0.90 & 164.40 & 15.82 & 63.43 & 15.25 & 25.01 \\
\hline EWTB3 & $1025^{\circ} \mathrm{C}$ (6 min.) & 1.94 & 268.80 & 14.82 & 60.01 & 16.66 & 25.44 \\
\hline EWTB5 & $1025^{\circ} \mathrm{C}$ (6 min.) & 2.88 & 328.60 & 9.74 & 54.56 & 16.19 & 22.37 \\
\hline EWTB7 & $1025^{\circ} \mathrm{C}$ (6 min.) & 8.42 & 458.20 & 0.56 & 41.42 & 9.87 & 13.17 \\
\hline EWTB10 & $1025^{\circ} \mathrm{C}(6 \mathrm{~min})$. & 7.84 & - & 0.00 & 40.20 & 8.51 & 12.94 \\
\hline SWTB & $1182{ }^{\circ} \mathrm{C}(6 \mathrm{~min})$. & 1.01 & 203.18 & 15.78 & 72.11 & 9.89 & 19.47 \\
\hline EWTB1 & $1025^{\circ} \mathrm{C}(30 \mathrm{~min})$. & 1.36 & 162.00 & 15.39 & 62.03 & 12.96 & 21.37 \\
\hline EWTB3 & $1025^{\circ} \mathrm{C}(30 \mathrm{~min})$. & 2.70 & 244.00 & 10.93 & 56.44 & 13.37 & 20.63 \\
\hline EWTB5 & $1025^{\circ} \mathrm{C}(30 \mathrm{~min})$. & 4.58 & 274.00 & 7.00 & 50.04 & 12.10 & 17.40 \\
\hline EWTB7 & $1025^{\circ} \mathrm{C}(30 \mathrm{~min})$. & 6.92 & 341.00 & 2.95 & 40.91 & 10.55 & 14.54 \\
\hline EWTB10 & $1025^{\circ} \mathrm{C}(30 \mathrm{~min})$. & 6.54 & 338.00 & 0.28 & 38.90 & 8.82 & 12.80 \\
\hline
\end{tabular}

*min: minutes

\subsection{Microstructural Analysis}

Figures $4 \mathrm{a}$ and $\mathrm{b}$ show SEM images of SWTB fired at $1182{ }^{\circ} \mathrm{C}$ and EWTB5 fired at $925{ }^{\circ} \mathrm{C}$ for 6 minutes, respectively. The dark grey areas are distinguished as the glassy matrix phase, whereas black areas indicate the pores. The comparison of Figures $4 \mathrm{a}$ and $\mathrm{b}$ revealed that UCW acted as a low temperature auxiliary flux and decreased the viscosity of the glassy phase. Enhanced vitrification caused the transformation of the larger pores (Figure 4a) mostly into the smaller closed pores in EWTB5 (Figure 4b). The structure of EWTB5 was denser due to improved vitrification (Figure 4b), which was also justified by higher FBS value of $208.60 \mathrm{~kg} / \mathrm{cm}^{2}$ than $203.18 \mathrm{~kg} / \mathrm{cm}^{2}$ of SWTB. 


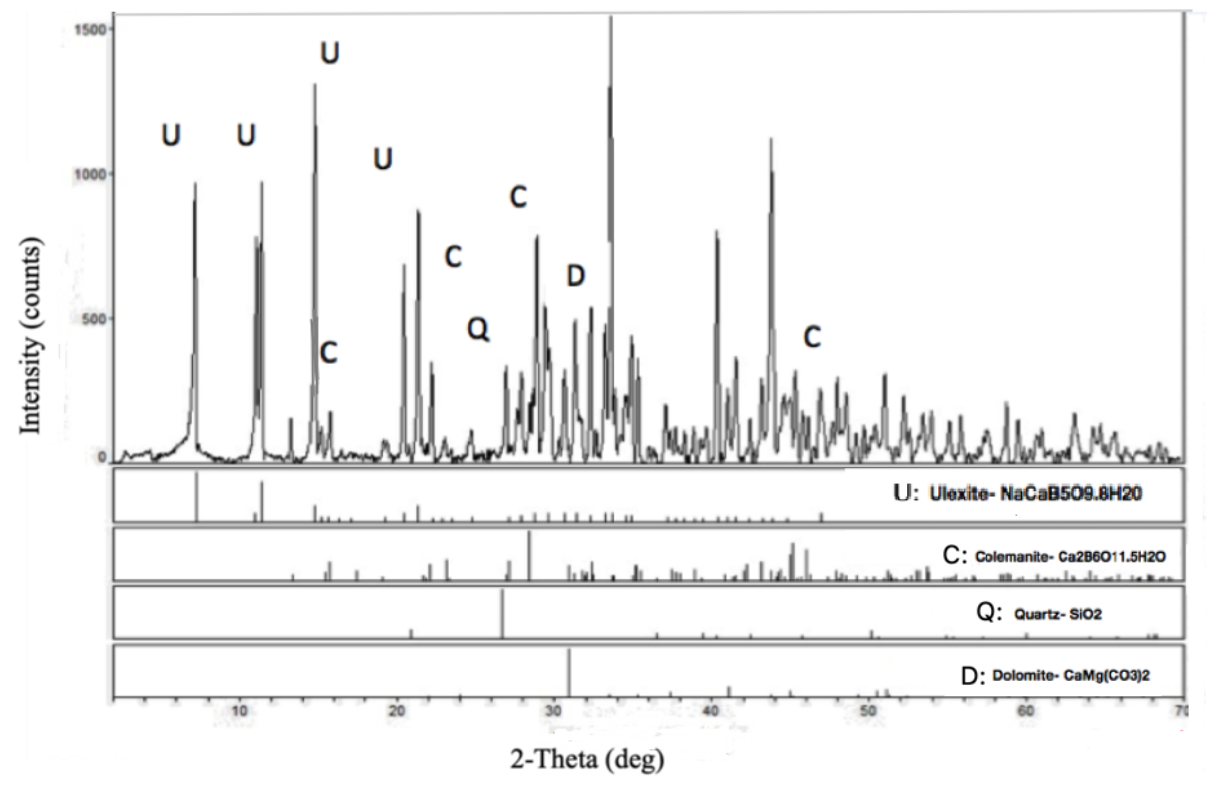

Figure 1. XRD spectra of UCW.

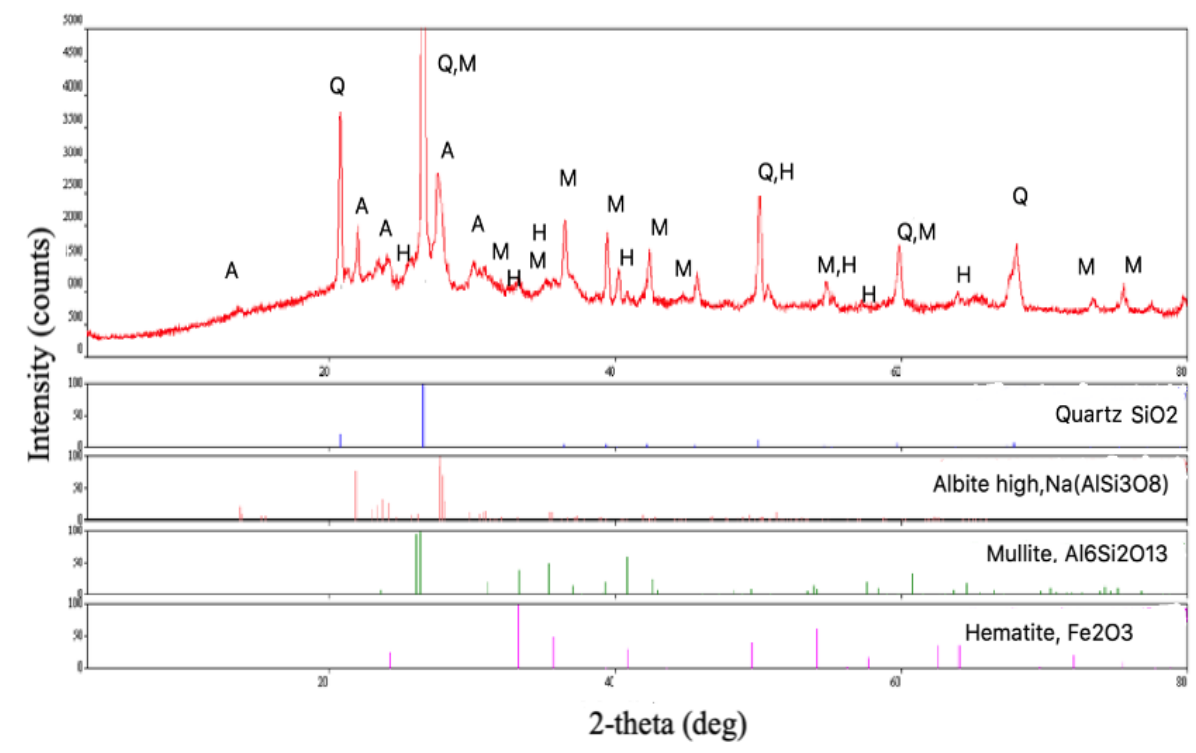

Figure 2. XRD spectra of SWTB.

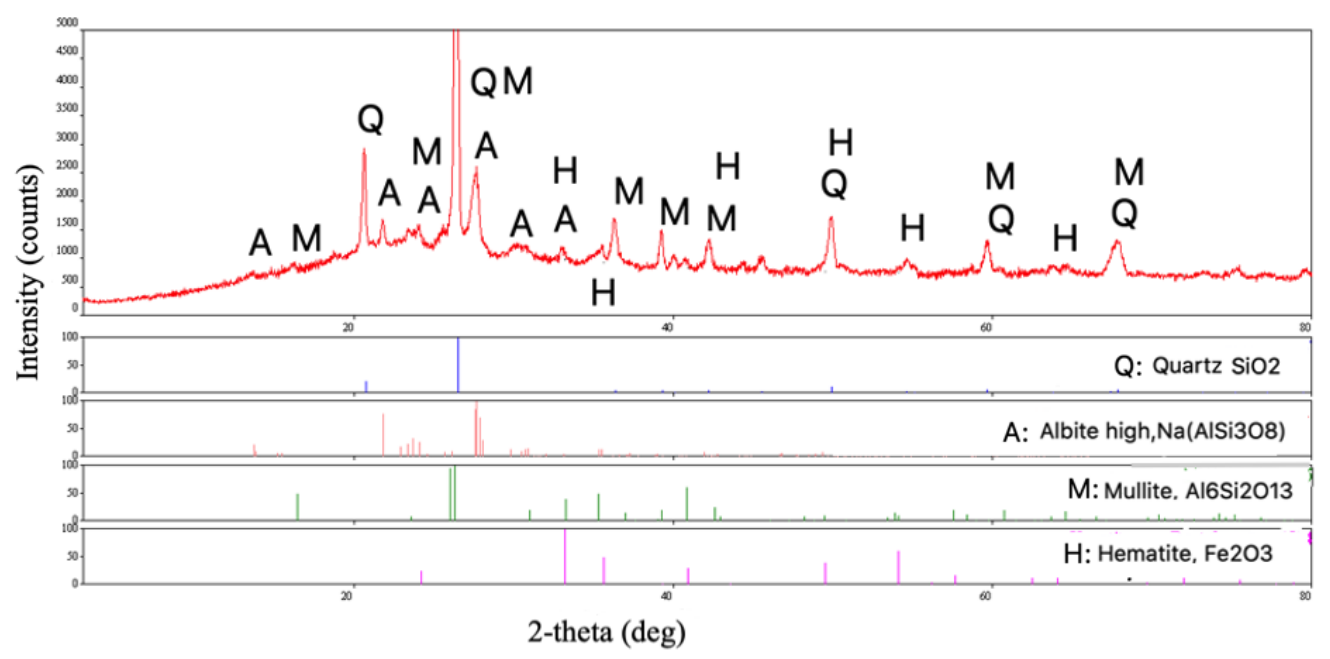

Figure 3. XRD spectra of EWTB5. 

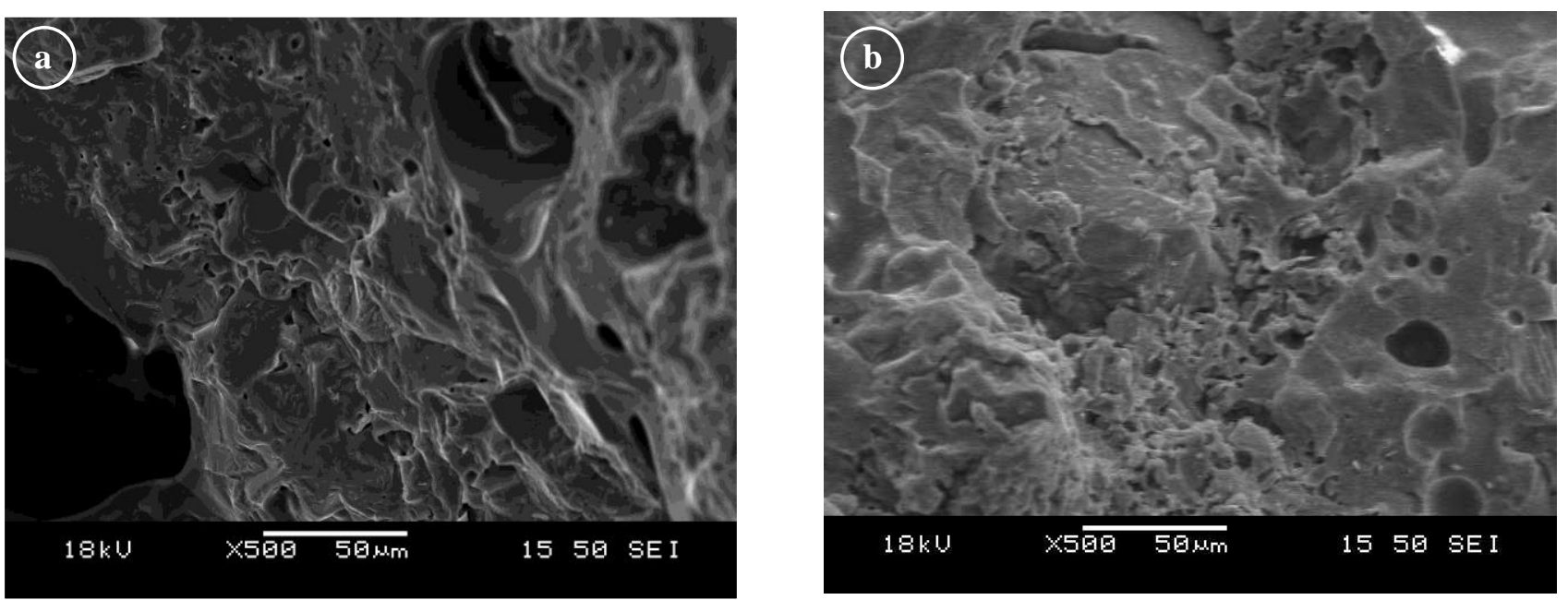

Figure 4. SEM images of SWTB and EWTB5 samples. (a) fired at $1182{ }^{\circ} \mathrm{C}$. (b) fired at $925^{\circ} \mathrm{C}$.

The area of EDX analyses of SWTB (Figure 5a) and of EWTB5 (Figure 5b) were taken and showed that both SWTB and EWTB5 contained $\mathrm{Al}, \mathrm{Si}, \mathrm{Na}, \mathrm{K}, \mathrm{Ca}$, elements, which was in good agreement with the chemical analysis of the raw materials (Table 1), UCW, the XRD analyses of SWTB and EWTB5. The area EDX analyses indicated the presence of $\mathrm{Zr}$ which was due to contamination of the raw materials with glaze during production at the plant.

\subsection{Colorimetric Analysis}

The values of the chromatic coordinates $(\mathrm{L}, \mathrm{a}$, and b) of the SWTB and EWTB formulations were given in Table 5. Whiteness index was denoted as $\mathrm{L}$, variations between green and red colours was denoted as a, and variations between blue and yellow colours was denoted as b (Hunter and Harold, 1987; URL-2). The L (lightness or whiteness) values of EWTB decreased with an increase in UCW content. Higher UCW contents caused a decrease in whiteness (Figures 6, 7, and 8). This can be attributed to the improved vitrification or the gradual increase in the amount of glassy matrix with an increase in UCW content. $a$ and $b$ values generally showed an increase and then decrease for all compositions, dwelling times and sintering temperatures as UCW content increased. Increasing a values indicated a shift towards redness, which caused the colours of the EWTB to darken. Increasing $b$ values indicated a shift towards yellowness, which caused the colours of the EWTB to lighten.

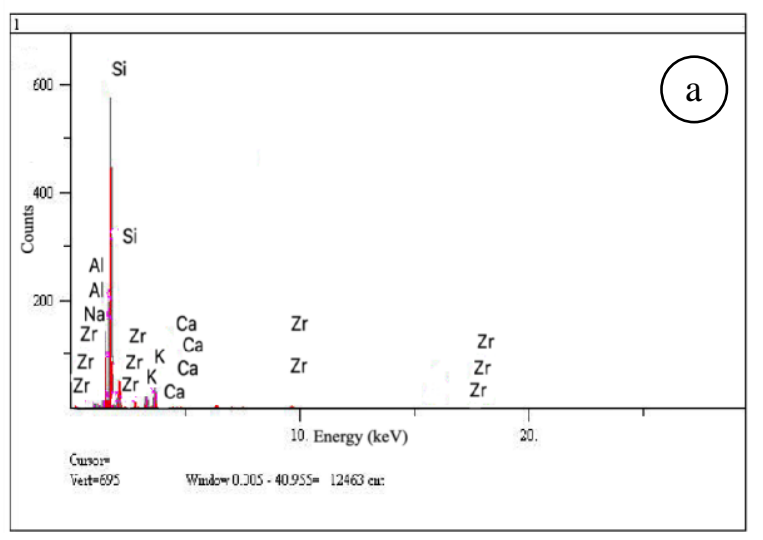

Figure 5. EDX analysis of SWTB and EWTB5 samples. (a) fired at $1182{ }^{\circ} \mathrm{C}$. (b) fired at $925^{\circ} \mathrm{C}$.

\section{Conclusions}

The aim of this laboratory research work was to utilize UCW, which causes environmental pollution and accumulates in large quantities in

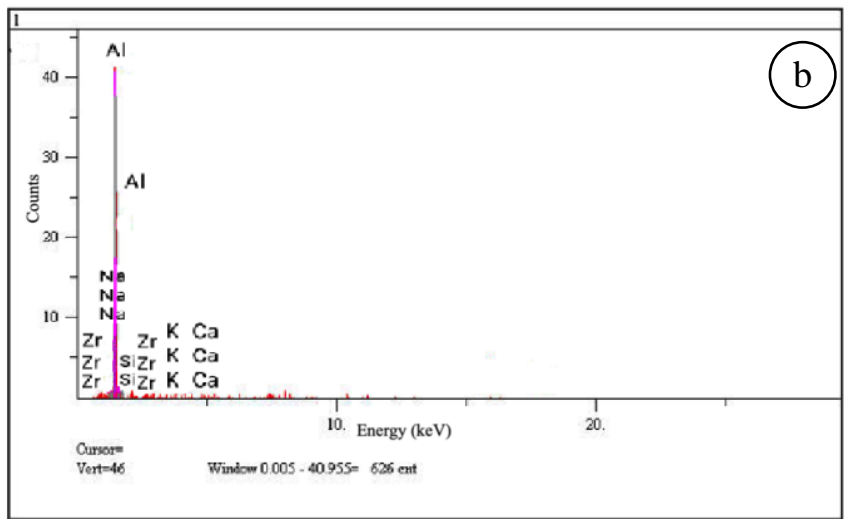

the vicinity of boron concentrator plants, as an additive to a SWTB recipe. The physical and mechanical properties of EWTB, XRD and SEM analyses clearly revealed that the optimal EWTB composition was that of EWTB5 containing 5 wt. 
\% UCW fired at $925{ }^{\circ} \mathrm{C}$ with a dwell time of 6 minutes. LFS, WA, and FBS values of EWTB5 were respectively $0.60 \%, 16.15 \%$, and 208.60 $\mathrm{kg} / \mathrm{cm}^{2}$ which were all in conformity with the related WT standards. Addition of 5\% UCW to the SWTB improved the physical and mechanical properties. Thus, EWTB5 represented even better physico-mechanical properties than those of the SWTB produced at the factory under industrial conditions. Furthermore, the sintering temperature was considerably reduced from $1182{ }^{\circ} \mathrm{C}$ down to $925{ }^{\circ} \mathrm{C}$ which corresponds to a $257^{\circ} \mathrm{C}$ reduction compared to the industrial firing temperature of $1182^{\circ}$. Using UCW in WT recipe will be beneficial from economic and environmental viewpoints. Furthermore, better physical and mechanical properties would be additional benefits.

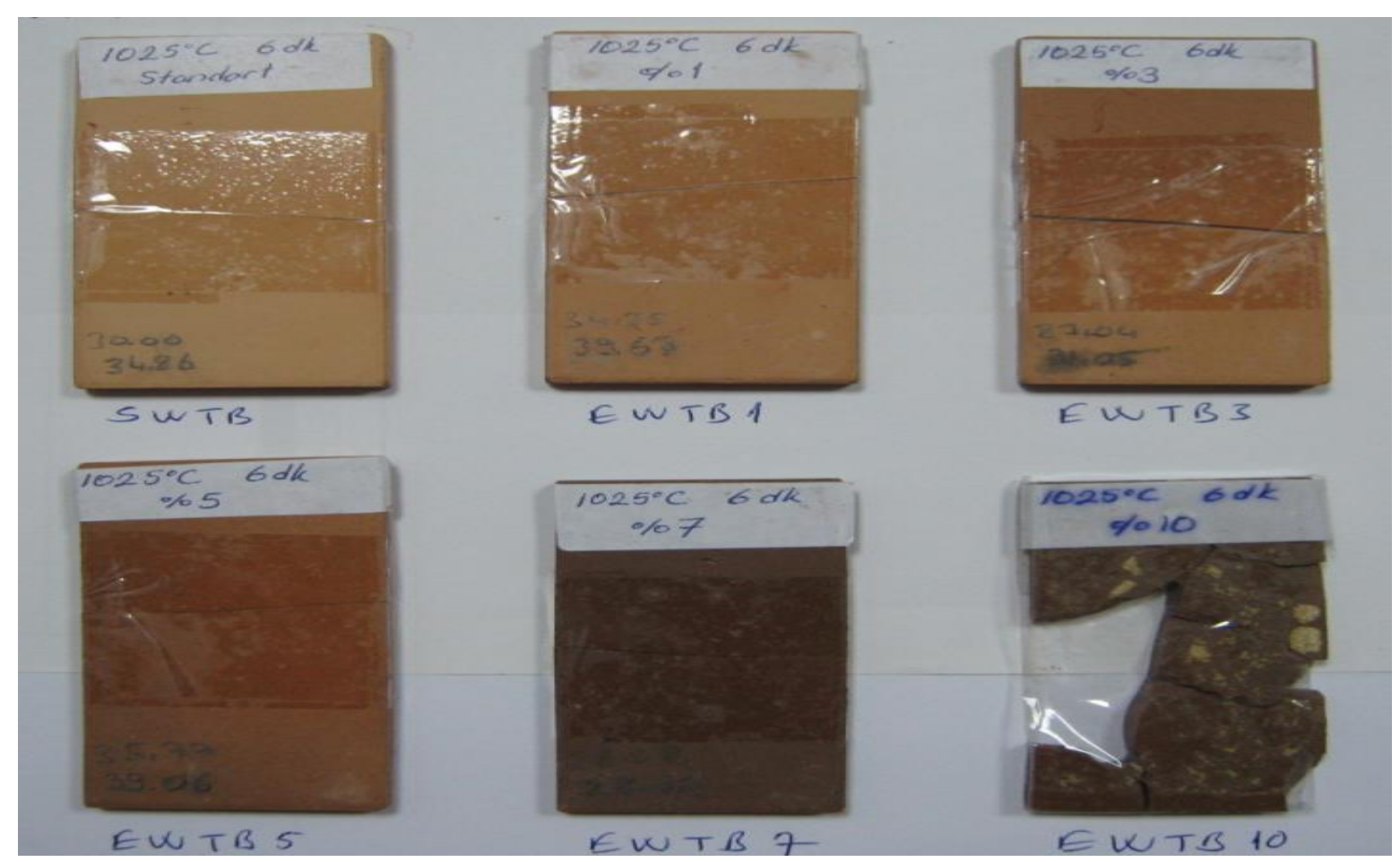

Figure 6. Photographs of EWTB fired at $925{ }^{\circ} \mathrm{C}$ and subjected to FBS test.

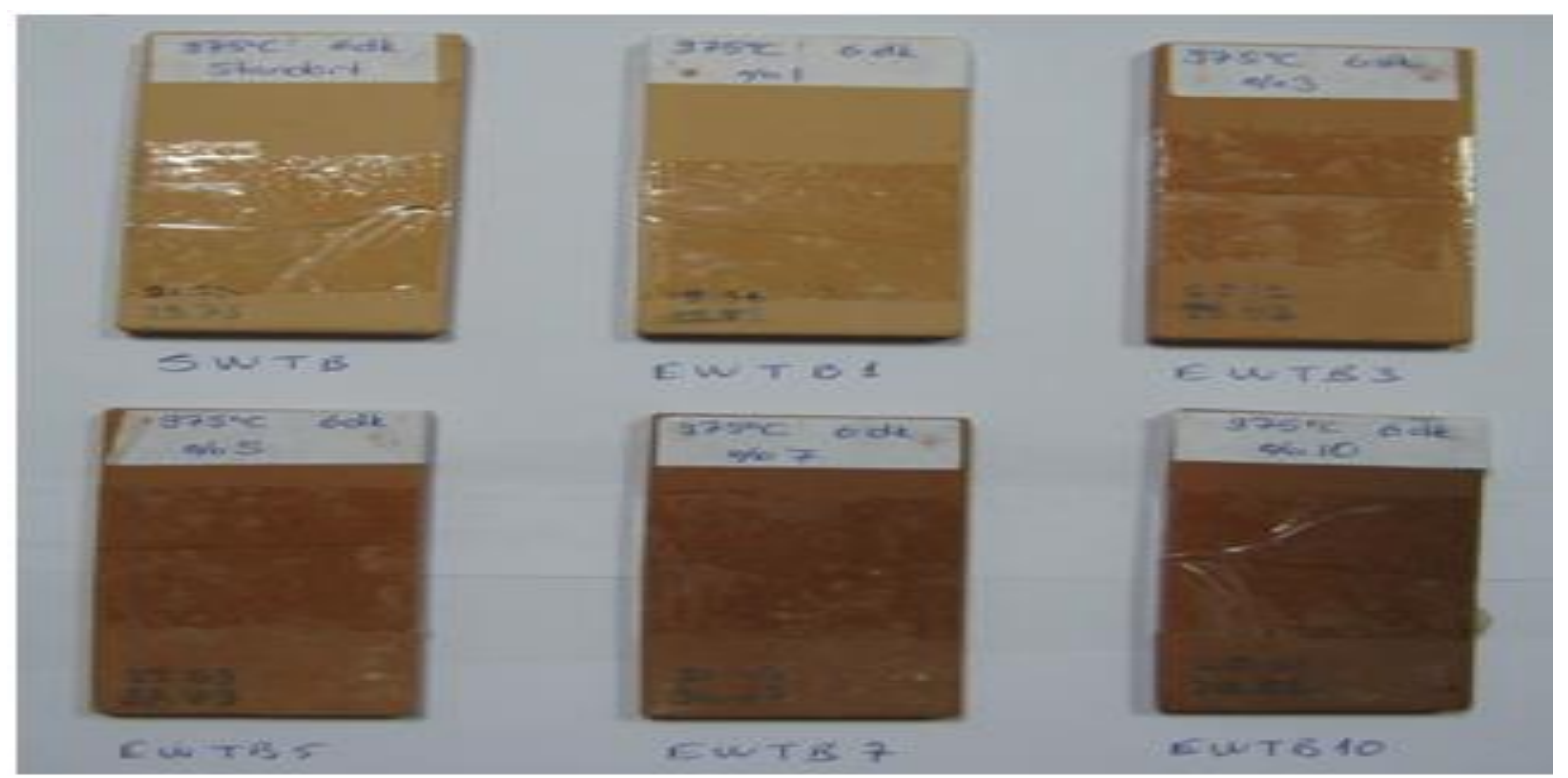

Figure 7. Photographs of EWTB fired at $975{ }^{\circ} \mathrm{C}$ and subjected to FBS test. 


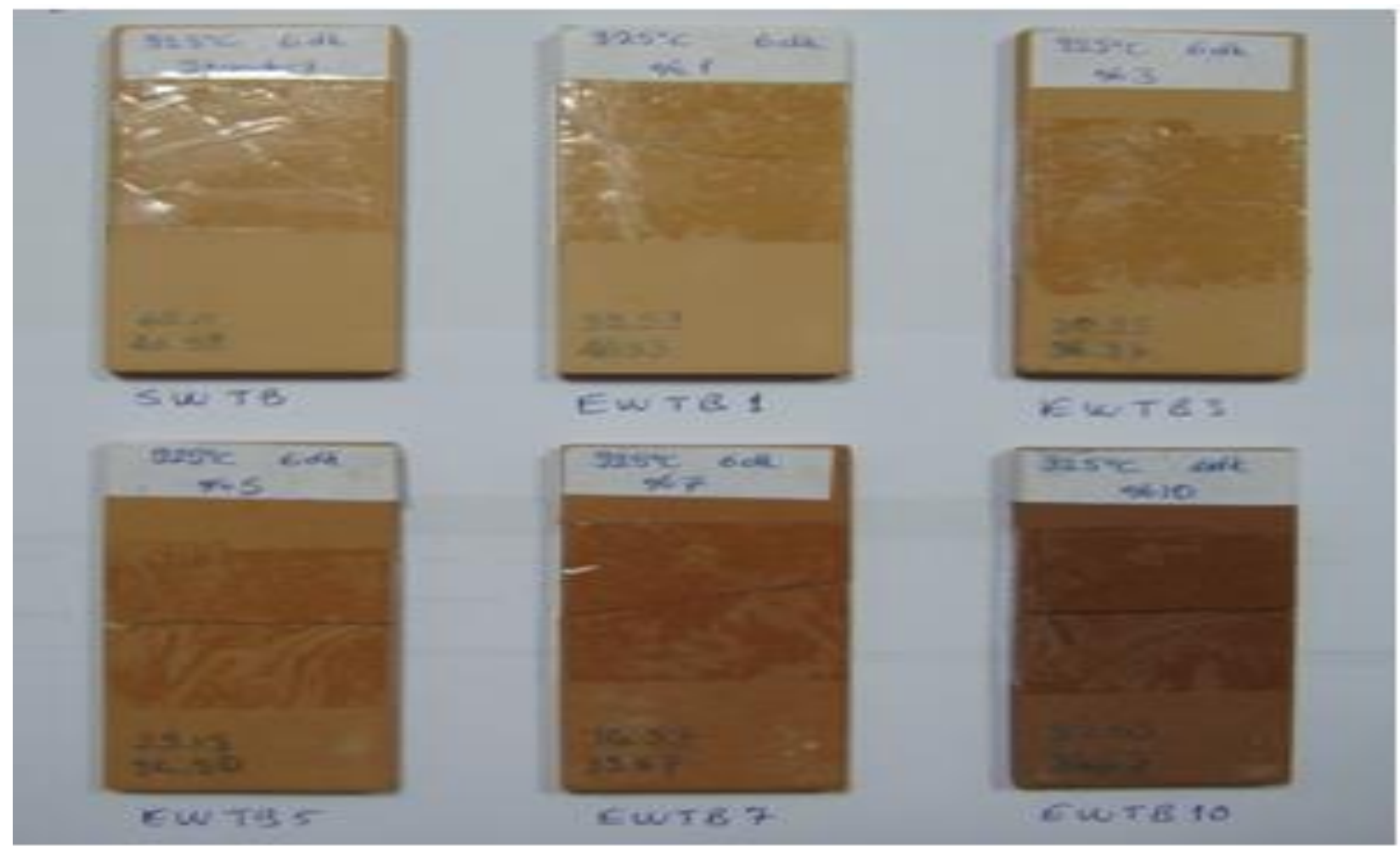

Figure 8. Photographs of EWTB fired at $1025^{\circ} \mathrm{C}$ and subjected to FBS test.

\section{Acknowledgements}

This research did not receive any specific grant from funding agencies in the public, commercial, or not-for-profit sectors. The authors would like to thankfully acknowledge Ege Seramik Inc., the manager of Ege Seramik factory and the authorized personnel of the chemical laboratory for their valuable help.

\section{References}

Alp, Y., 2005. Ceramic Tile, The Survey Report of the Foreign Trade Board of the Istanbul Chamber of Commerce, Istanbul, 24p.

Baele, S. M., 1998. Borate is an Important Ingredient in Glass Fiber Manufacture. Glass, 75, 420427.

Bayça, S.U., 2009. Effects of the Addition of Ulexite to the Sintering Behaviour of a Ceramic Body, Journal of Ceramic Processing Resolutions, 10, 162-166.

Boncukcuoğlu, R., Kocakerim, M.M., Kocadağistan E. and Yilmaz M.T., 2003. Recovery of Boron of the Sieve Reject in the Production of Borax, Resources Conservation Recycling, 37, 147157.

Carter, C.B. and Norton, M.G., 2013. Ceramic Materials: Science and Engineering: New York, Springer-Verlag, 766p.
Coble, R.L., 1961. Sintering Crystalline Solids, Journal of Applied Physics, 32, 793-799.

Coble, R.L. and Burke, J.E., 1963. Sintering in Ceramics, in: Progress in Ceramic Science Volume 3, J.E. Burke (ed.), Pergamon Press, London, pp. 197-251.

Çelik, H., 2015. Recycling of Boron Waste to Develop Wall Tile in Turkey, Transactions of Indian Ceramic Society, 74, 108-116.

Ediz N., Yurdakul, H. and Issi, A., 2004. Use of Tincal Waste as a Replacement for Calcite in Wall Tile Production, Key Engineering Materials, 264268, 2457-2460.

Ediz, N. and Yurdakul, A., 2009. Characterization of Porcelain Tile Bodies with Colemanite Waste Added as a New Sintering Agent, Journal of Ceramic Processing Resolutions., 10, 414-422.

Glendenning, M. D. and Lee, W. E., 1996. Microstructural Development on Crystallising Hot-pressed Pellets of Cordierite Melt-derived Glass Containing $\mathrm{B}_{2} \mathrm{O}_{3}$ and $\mathrm{P}_{2} \mathrm{O}_{5}$, Journal of American Ceramic Society, 79, 705-713.

Hunter, R.S. and Harold, R.W, 1987. The Measurement of Appearance: New York, John Wiley and Sons, Inc., 432p.

Karasu, B., Kaya, G. and Yurdakul, H., 2002. Effect of the Etibor Kirka Borax Company's Concentration and Derivation Wastes on the 
Properties of Wall Tile Body, Proceedings of $1^{\text {st }}$ International Boron Symposium, Kütahya, $\mathrm{p}$. 224.

Karasu, B., Kaya, G., Yurdakul, H. and Topkaya, A., 2002. Use of Borax Solid Wastes in Wall Tile Bodies and its Effect on Microstructure, Boron Symposium, Balıkesir, Book of abstracts, p.18.

Karasu, B., Kaya, G., Yurdakul, H. and Topkaya, A., 2002. The Efforts on Utilization of Borax Solid Wastes in wall Tile Bodies, 104 ${ }^{\text {th }}$ Annual Meeting \& Exposition of the American Ceramic Society, St. Louis, Book of abstracts, p. 274.

Karasu, B., Yurdakul, H. and Kaya, G., 2004. Use of Borax Solid Wastes in the Receipes of Wall Tile Bodies as a Fluxing Agent and Their Effects on the Microstructures, Journal of Turkish Ceramic Federation, 6, 135-145 (in Turkish).

Karasu, B., 2007. Use of Borax Solid Wastes in Ceramics' World, Proceedings of the Xth Conference and Exhibition of the European Ceramic Society, Berlin, p. 1773.

Kavas, T., Christogerou, A., Pontikes, Y. and Angelopoulos, G.N., 2011. Valorisation of Different Types of Boron-Containing Wastes for the Production of Lightweight Aggregates, Journal of Hazardeous Materials, 185, 13811389.

Köseoğlu, K., 2017. Effect of Ulexite Concentrator Waste on the Physical and Mechanical Properties and Sintering Behaviour of Floor Tile Bodies, Clay Minerals, 52, 97-105.

Kurama, S., Kara, A. and Kurama, A., 2006. The Effect of Boron Waste in Phase and Microstructural Development of a Terracotta Body During Firing, Journal of European Ceramic Society, 26, 755-760.
Kurama, S., Kara, A. and Kurama, A. 2007. Investigation of Borax Waste Behaviour in Tile Production, Journal of European Ceramic Society, 27, 1715-1720.

Levinkas, G. J., 1964. Boron, Metallo-Boron Compounds and Boranes, in: Toxicology of Boron Compounds, R. M. Adams (Ed.), Interscience Publishers, New York, pp. 700765 .

Önal, G. and Burat, F., 2008. Boron Mining and Processing in Turkey, Gospodarka Surowcamı Mineralnymi, 24, 49-60.

Sezzi, G., 2004. World Production and Consumption of Ceramic Tiles, Ceramic World Review., 58, 5471.

Singer, F. and Singer, S.S., 1984. Industrial Ceramics: New York, Chapman and Hall Ltd, 1139p.

Thümmler, F. and Thomma, W., 1967. The Sintering Process, International. Materials Reviews.,12, 69-108.

TS EN ISO 10545-2 2000. Ceramic Tiles Part 2, Determination of Dimensions and Surface Quality.

TS EN ISO 10545-3 2000. Ceramic Tile Part 2, Determination of Water Absorption, Apparent Porosity, Apparent Relative Density and Bulk Density.

TS EN ISO 10545-4 2000. Ceramic Tile Part 4, Determination of Modulus of Rupture and Breaking Strength.

URL-1, http://en.etimaden.gov.tr/.r12 February 2018).

URL-2, http://www.hunterlab.com/appnotes/an08_96a.p df. 